\title{
The photochemistry of some pyranopyrazoles
}

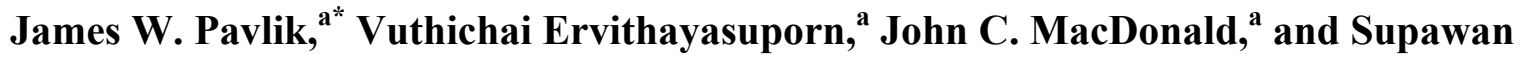 \\ Tantayanon $^{\mathrm{b}}$ \\ ${ }^{a}$ Department of Chemistry and Biochemistry, Worcester Polytechnic Institute Worcester, MA \\ 01609 \\ ${ }^{b}$ Department of Chemistry, Chulalongkorn University, Bangkok.10330, Thailand \\ E-mail:jwpavlik@wpi.edu
}

Dedicated to Professor Nicolo Vivona on his $\mathbf{7 0}^{\text {th }}$ birthday

\begin{abstract}
Irradiation of 1,3,6-trimethylpyrano [2,3-c] pyrazole-4 (1H)-one (1) or 3,6-dimethyl-1phenylpyrano [2,3-c]pyrazole-4-(1H)-one (2) in acetonitrile solution at $254 \mathrm{~nm}$ resulted in the formation of the cis-head-to-tail [2+2] dimers 5 or $\mathbf{1 3}$ respectively. When the irradiation was carried out in ethanol solvent 1 or $\mathbf{2}$ underwent dimerization to yield $\mathbf{5}$ or $\mathbf{1 3}$ respectively and also photocleavage to provide ethyl 5-hydroxy-1,3-dimethyl-1H-pyrazole-4-carboxylate (10) or ethyl 5-hydroxy-3-methyl-1-phenyl-1H-pyrazole-4-carboxylate (14) respectively.
\end{abstract}

Keywords: Pyranopyrazoles, photodimerization, photocleavage

\section{Introduction}

The photochemical properties of pyranopyrazoles are intriguing because the molecule can be viewed as a 4-pyrone ring fused on to a pyrazole ring. 4-Pyrones are known to undergo a variety of photochemical reactions including photodimerization, ${ }^{1-4}$ photoisomerization to 2-pyrones, ${ }^{5-10}$ and photo ring contraction to yield 4-hydroxy- cyclopentenone solvent adducts. ${ }^{11-14}$ The photochemistry of $\mathrm{N}$-substituted pyrazoles has also been extensively studied and these compounds have been found to undergo photoisomerization to imidazoles ${ }^{15-21}$ and photocleavage to yield enaminonitriles and enaminoisocyanides. ${ }^{18-21}$ Although the photochemistry of the individual ring systems have been studied, we are unaware of any reports concerning the photochemistry of the pyranopyrazole ring system. Because of our interest in these compounds, we have undertaken a study of the photochemistry of 1,3,6-trimethylpyrano [2,3-c] pyrazole4(1H)-one (1) and of 3,6-dimethyl-1-phenylpyrano[2,3-c] pyrazole-4(1H)-one (2). The results of that study are the subject of this manuscript. 


\section{Results and Discussion}

Pyranopyrazoles $\mathbf{1}$ and $\mathbf{2}$ were synthesized in two steps from the methyl- or phenylhydrazone 3a or $\mathbf{3 b}$ via the diketopyrazoles $\mathbf{4 a}$ or $\mathbf{4 b}$ respectively, according to a modification of the method developed by Gelin and colleagues ${ }^{22,23}$ (Scheme 1).

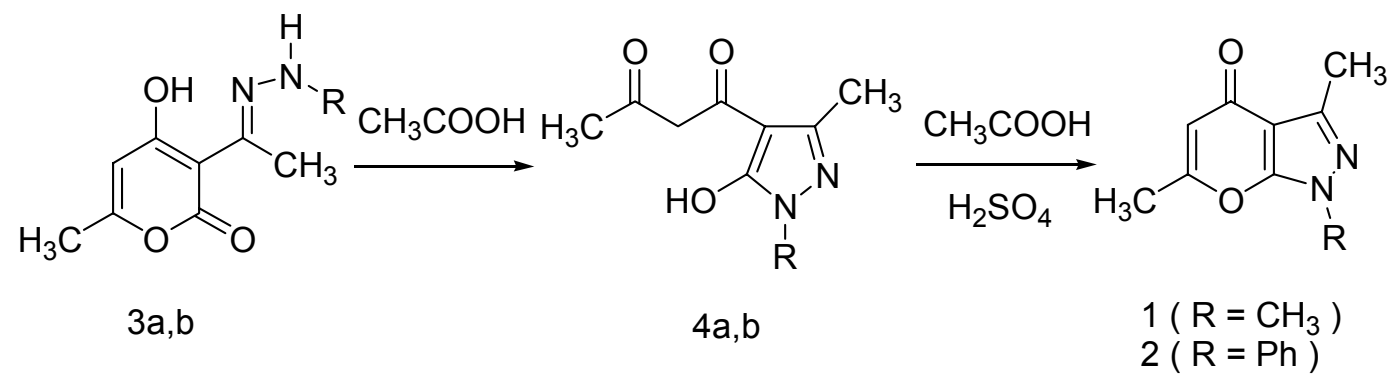

a: $\mathrm{R}=\mathrm{CH}_{3} ; \mathrm{b}: \mathrm{R}=\mathrm{Ph}$

\section{Scheme 1}

The UV-absorption spectra of $\mathbf{1}$ and $\mathbf{2}$ in acetonitrile solution exhibited absorption maxima at $250 \mathrm{~nm}\left(\varepsilon=9,068 \mathrm{~L} \mathrm{~mol}^{-1} \mathrm{~cm}^{-1}\right)$ and $206.0 \mathrm{~nm}\left(\varepsilon=14,764 \mathrm{~L} \mathrm{~mol}^{-1} \mathrm{~cm}^{-1}\right)$ and at $242.5 \mathrm{~nm}(\varepsilon=$ $\left.24,646 \mathrm{~L} \mathrm{~mol}^{-1} \mathrm{sec}^{-1}\right)$ respectively. Considering the magnitude of these extinction coefficients, these absorptions were assigned to $S_{0}$ to $S_{1}\left(\pi, \pi^{*}\right)$ and $S_{0}$ to $S_{2} \quad\left(\pi, \pi^{*}\right)$ in the case of 1 and to $\mathrm{S}_{0}$ to $\mathrm{S}_{1}\left(\pi, \pi^{*}\right)$ in the case of $\mathbf{2}^{25}$

A solution of $1\left(3.0 \mathrm{~mL}, 2.0 \times 10^{-2} \mathrm{M}\right)$ in acetonitrile was irradiated at $254 \mathrm{~nm}$. HPLC analysis as a function of irradiation time showed a continuous decrease in the peak area at 7.3 minutes due to the consumption of the reactant and the appearance of a new peak at 6.7 minutes due to the formation of a photoproduct 5. Analysis revealed, however, that the rate of reactant consumption decreased after 45 minutes of irradiation. Analysis also revealed that the area of the photoproduct 5 peak at 6.7 minutes increased during the first 45 minutes of irradiation and then slowly decreased upon longer irradiation time. This indicates that after 45 minutes of irradiation the product competes with the reactant for the incident light and begins to be consumed in a secondary photoreaction.

A solution of 1 was also irradiated at $254 \mathrm{~nm}$ on a preparative scale $\left(20.0 \mathrm{~mL}, 2.0 \times 10^{-2} \mathrm{M}\right)$ in acetonitrile until HPLC analysis indicated maximum formation of 5 . Preparative-layer chromatography of the resulting solution allowed isolation of a white crystalline product, $\mathrm{mp}$ $229-230^{\circ} \mathrm{C}$. HPLC analysis of this solid showed a single peak with a retention time identical to the retention time of photoproduct $\mathbf{5}$ observed during the analytical-scale irradiation. This confirms that the isolated product is the observed photoproduct 5 .

The mass spectrum of $\mathbf{5}$ exhibited a molecular ion at $\mathrm{m} / \mathrm{z}=356$, exactly twice the mass of the reactant $\mathbf{1}$, indicating that $\mathbf{5}$ is a dimer of $\mathbf{1}$. The molecular mass and elemental analysis are consistent with the molecular formula $\mathrm{C}_{18} \mathrm{H}_{20} \mathrm{~N}_{4} \mathrm{O}_{4}$, the correct formula for a dimer. 
The ${ }^{1} \mathrm{H}$ NMR spectrum of 5 shows singlets at $\delta 1.78,2.28,3.41$, and 3.22 with an integrated ratio of 3:3:3:1. Thus, although the molecular formula is consistent with the presence of six methyl groups, the ${ }^{1} \mathrm{H}$ NMR spectrum exhibits three different sets of methyl protons. Each set must therefore contain two methyl groups. Similarly, the ${ }^{13} \mathrm{C}$ NMR spectrum shows the presence of nine different sets of carbon atoms. Since the molecular formula shows that $\mathbf{5}$ contains 18 carbon atoms, each set must contain two identical carbon atoms. The ${ }^{1} \mathrm{H}$ and ${ }^{13} \mathrm{C}$ NMR spectra indicate that the dimer 5 must have a symmetrical structure. Structures consistent with this include the cis or trans-head-to-head $(\mathbf{5 a}$ or $\mathbf{5 b})$ or head-to-tail $(\mathbf{5 c}$ or $\mathbf{5 d})[2+2]$ cycloaddition adducts shown in Scheme 2.<smiles>Cc1nn(C)c2c1C(=O)C1OC3(C)OC4(C)OC21c1c(C)nn(C)c1OC34C</smiles>

$5 a$

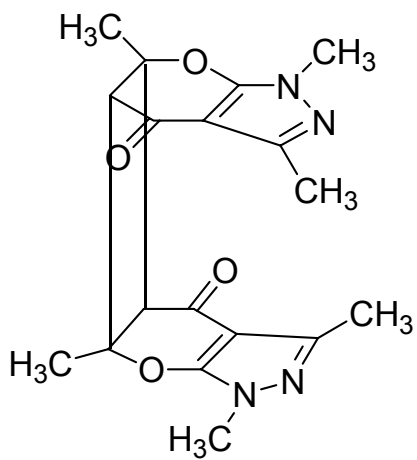

$5 c$

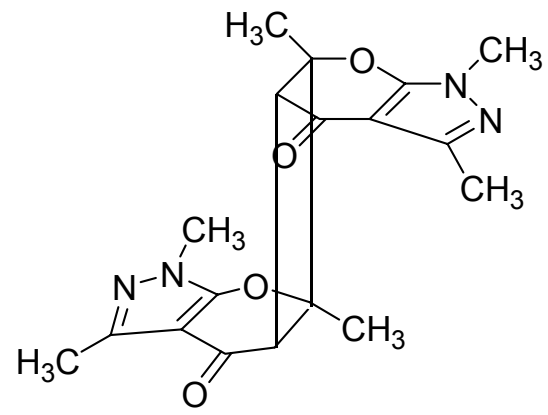

$5 b$

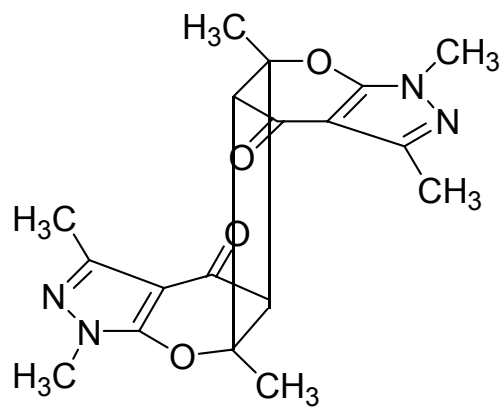

$5 d$

\section{Scheme 2}

These structures are analogous with the known head-to-tail [2+2] dimer 7 obtained from the photodimerization of 2,6-dimethyl-4-pyrone $6^{3,4}$ and head-to-tail [2 +2 ] dimer 9 obtained from photodimerization of 2,3-dihydro-2,2-dimethyl-4H-pyran-4-one 8 shown in Scheme $3 .^{26}$ 

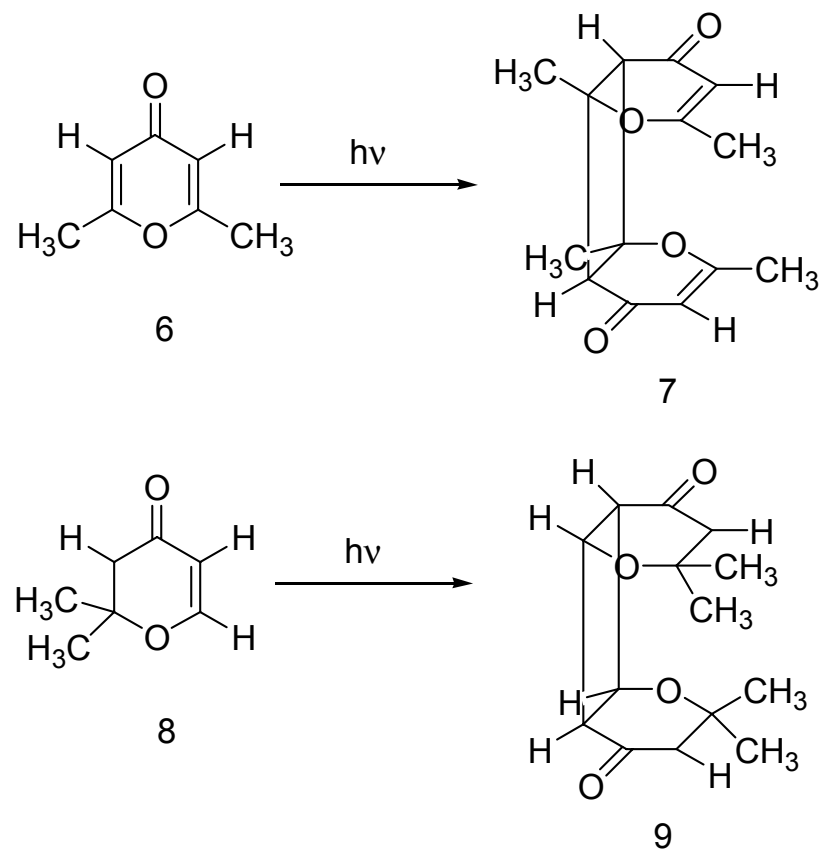

\section{Scheme 3}

Single crystal X-ray diffraction analysis allowed distinction among these possibilities and confirmed that the structure of the photoproduct 5 is the cis-head-to-tail [2+2] cycloaddition dimer shown as 5c in Scheme 2. The crystal structure of 5c is shown in Figure 1. The conformations and structures of the cyclobutane ring and dihydropyranone rings in $\mathbf{5 c}$ are consistent to those reported for 7 and 9.

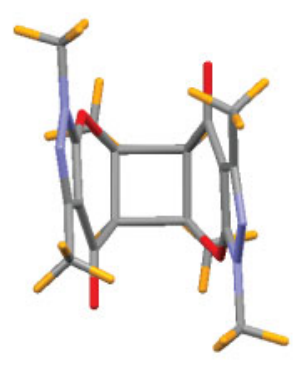

a

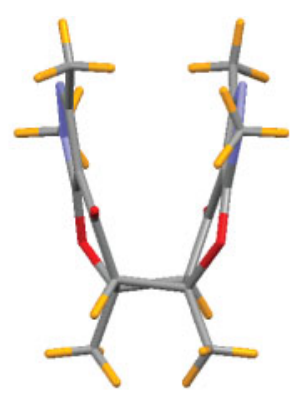

b

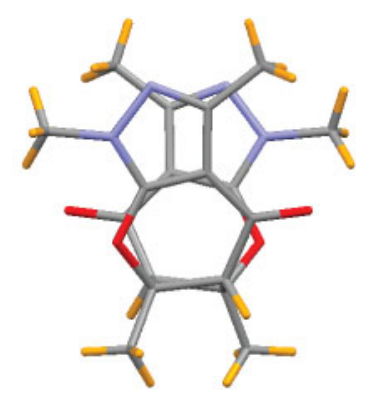

C

Figure 1. Crystal structure of the cis-head-to-tail [2+2] cycloaddition dimer $\mathbf{5 c}$ viewed from above (a) and from the sides ( $b$ and $c$ ) of the cyclobutane ring.

HPLC analysis as a function of irradiation time showed that the yield of the dimer $\mathbf{5}$ reached a maximum of $35 \%$ after 45 minutes of irradiation and then slowly decreased upon longer irradiation. This indicates that after 45 minutes of irradiation the dimer $\mathbf{5}$ was being consumed faster than it was being formed. Irradiation of a pure sample of photodimer $\mathbf{5}$ revealed that it underwent a retro $[2+2]$ reaction leading back to $\mathbf{1}$. 
A solution of pyranopyrazole $1\left(20.0 \mathrm{~mL}, 2.0 \times 10^{-2} \mathrm{M}\right)$ in ethanol was also irradiated at 254 $\mathrm{nm}$. The ${ }^{1} \mathrm{H}$ NMR spectrum of the crude product mixture revealed singlets at $\delta 1.78,2.28,3.41$, and 3.22 due to formation of dimer $\mathbf{5}$ and additional signals due to the formation of a second product $\mathbf{1 0}$ which was not observed after irradiation of $\mathbf{1}$ in acetonitrile solvent. Preparativelayer chromatography led to the isolation of the dimer $\mathbf{5}$ and to $\mathbf{1 0}$ as a white crystalline compound, $\mathrm{mp} 124-125^{\circ} \mathrm{C}$.

The ${ }^{1} \mathrm{H}$ NMR spectrum of $\mathbf{1 0}$ revealed a $2 \mathrm{H}$ quartet and a $3 \mathrm{H}$ triplet $(\mathrm{J}=7.1 \mathrm{~Hz})$ at $\delta 4.28$ and 1.24 respectively. Thus, it appears that a molecule of ethanol has been incorporated into the photoproduct 10. The spectrum also shows a $3 \mathrm{H}$ singlet at $\delta 3.58$, consistent with an $\mathrm{N}$-methyl group, and a $3 \mathrm{H}$ singlet at $\delta 2.29$, consistent with an allyl methyl group. Significantly, although pyranopyrazole 1 has three methyl groups, the product has only two. One methyl group has been lost. In addition, the $1 \mathrm{H}$ singlet due to the $\alpha$-proton in the 4-pyrone ring in the reactant is not observed in the product. This suggests that the $\alpha$ and $\beta$ carbons of the pyrone ring have been lost during the photoreaction. Finally, the ${ }^{1} \mathrm{H}$ NMR spectrum exhibits a broad peak at $\delta 9.24\left(\mathrm{D}_{2} \mathrm{O}\right.$ exchangeable) due to the presence of a hydroxyl proton in the structure. The ${ }^{13} \mathrm{C}$ NMR spectrum shows the presence of eight sets of carbon atoms. These include the three methyl groups absorbing at $\delta 14.6,14.8$, and 33.3, and the methylene carbon of the ethoxy group absorbing at 660.7. Significantly, the ${ }^{13} \mathrm{C}$ NMR spectrum also exhibits a signal for a quaternary carbon at $\delta 167.2$, consistent with an ester carbonyl carbon, and signals for quaternary carbon atoms at $\delta 157.7,147.8$, and 92.7 , consistent with the $\mathrm{C} 3, \mathrm{C} 5$, and $\mathrm{C} 4$ atoms respectively of a pyrazole ring.

Taken together, the spectroscopic data suggests that photoproduct 10 is ethyl 5-hydroxy-1, 3dimethyl-1H-pyrazole-4-carboxylate. ${ }^{27}$ This proposed structure for $\mathbf{1 0}$ was confirmed by direct comparison of the spectroscopic properties of the isolated photoproduct with an authentic sample of ester $\mathbf{1 0}$ synthesized by acetylation of diethyl malonate $\mathbf{1 1}$ to provide acetyldiester $\mathbf{1 2}$ and treatment of the latter with methylhydrazine as shown in Scheme 4.

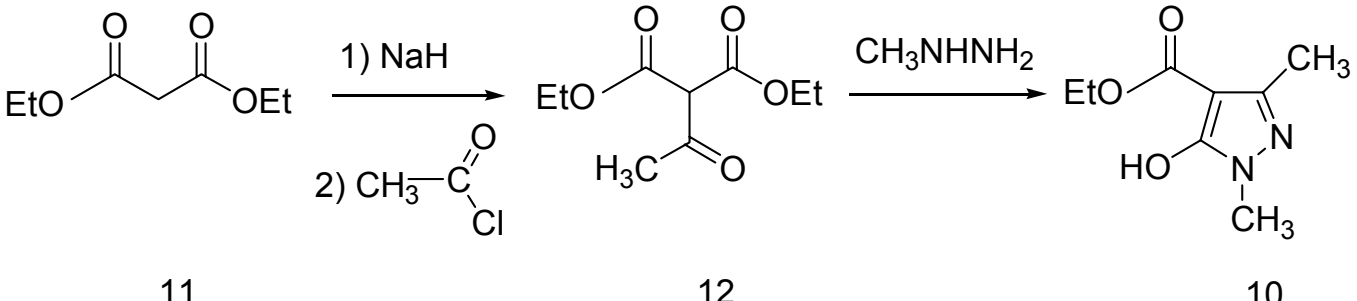

\section{Scheme 4}

The photoreaction of pyranopyrazole $\mathbf{1}$ in ethanol solvent is summarized in Scheme 5. 


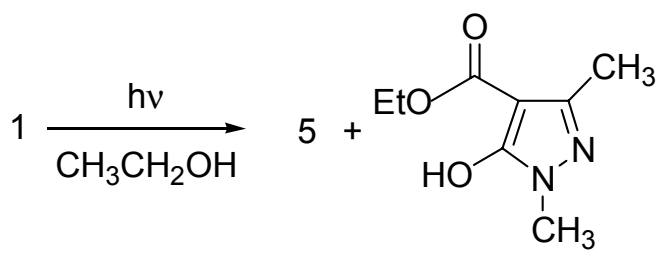

10

\section{Scheme 5}

The photochemistry of $N$-phenylpyranopyrazole 2 was analogous to the photochemistry of $N$ methylpyranopyrazole 1. Thus, as shown in Scheme 6, irradiation of 2 at $254 \mathrm{~nm}$ in acetonitrile solvent led to the formation of a single photoproduct 13, shown by mass spectroscopy, elemental analysis, and ${ }^{1} \mathrm{H}$ and ${ }^{13} \mathrm{C}$ NMR spectroscopy to be the cis-head-to tail dimer $\mathbf{1 3}$ formed in $58 \%$ yield.<smiles>CCOC(=O)c1c(C)nn(-c2ccccc2)c1O</smiles>

14

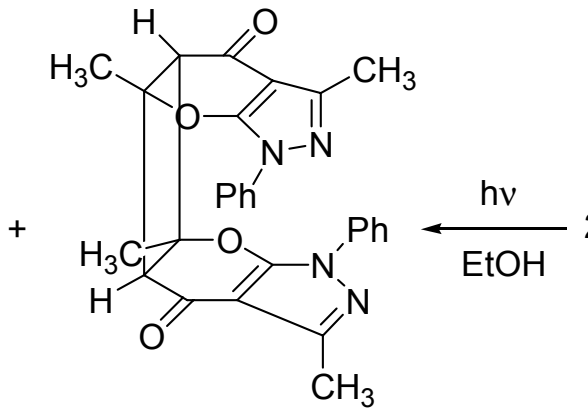

13

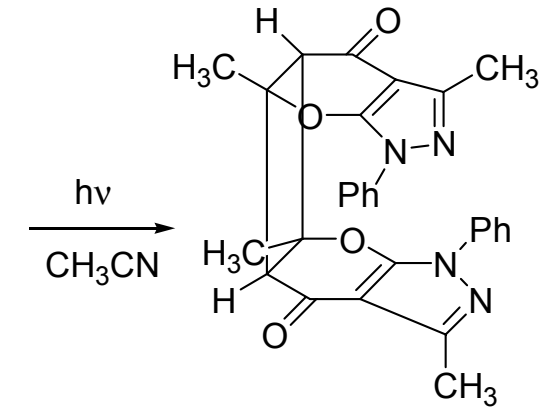

13

\section{Scheme 6}

Irradiation of $\mathbf{2}$ in ethanol, however, led to the formation of dimer $\mathbf{1 3}$ in $22 \%$ yield and to the formation of ethyl 5-hydroxy-3-methyl-1-phenyl-1H-pyrazole-4-carboxylate $14{ }^{28}$ The structure of ester 14 was confirmed by comparison of the photoproduct with an authentic sample of 14 synthesized in this laboratory.

The formation of photodimers $\mathbf{5}$ and $\mathbf{1 3}$ from $\mathbf{1}$ and $\mathbf{2}$ respectively is viewed as [2+2] cycloaddition reactions occurring from the $S_{1}\left(\pi, \pi^{*}\right)$ state of the pyranopyrazole in which the excitation energy is localized within the 4-pyrone ring. In alcohol solvent, it is suggested that the excited state partitions between [2+2] dimerization and 2,6-bridging, as shown in Scheme 7, to yield zwitterionic species 15. 


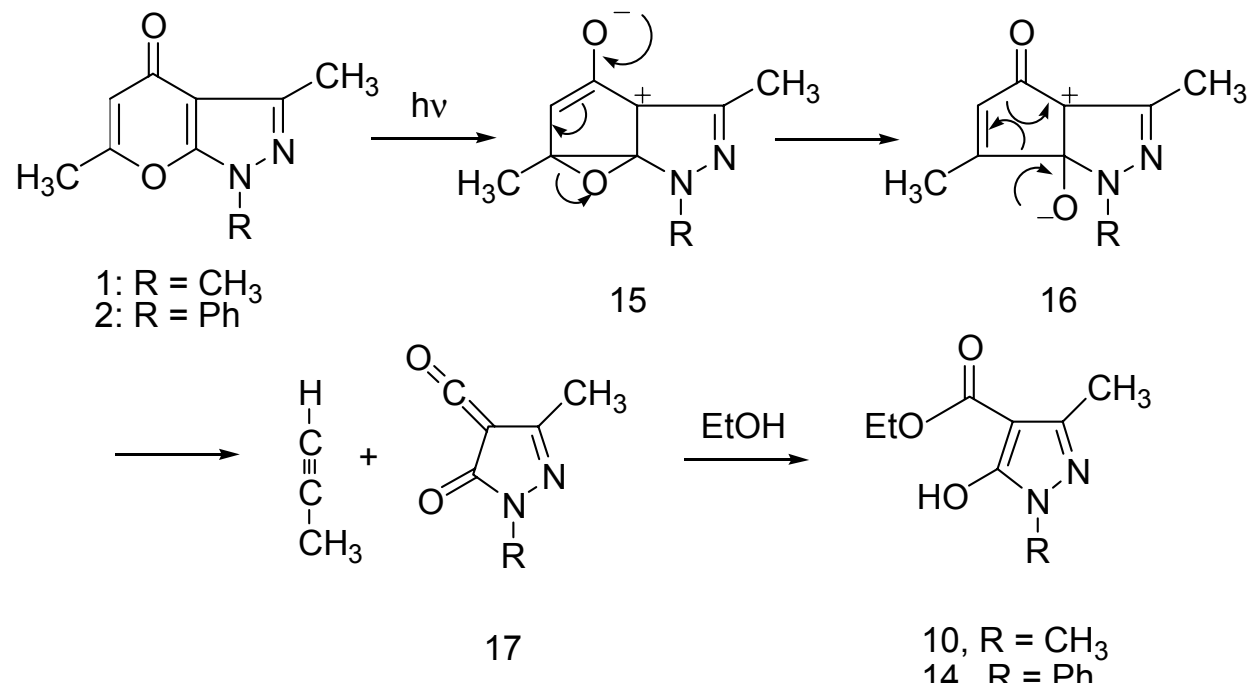

\section{Scheme 7}

Such 2,6-bridging is a well-established photochemical pathway for 4-pyrones and is known to be enhanced by the use of polar protic solvents. ${ }^{7}$ Although such photochemically generated zwitterions are generally trapped by nucleophilic solvents, such as alcohols, with simultaneous opening of the epoxide ring, ${ }^{10,11}$ in the present case it is suggested that $\mathbf{1 5}$ undergoes cleavage to yield ketene 17 via intermediate 16. Whereas such cleavage is not a known pathway for zwitterions photochemically generated from monocyclic 4-pyrones, in the present case it is plausible that the strain associated with two fused five-membered rings in $\mathbf{1 5}$ provides the driving force for cleavage of $\mathbf{1 6}$ to yield ketene 17. The latter species is then trapped by the alcohol solvents to yield the observed esters. As expected by this mechanistic suggestion, irradiation of pyranopyrazole $\mathbf{1}$ in methanol solvent led to the formation of dimer $\mathbf{5}$ and the methyl ester 18, analogous to 10, as shown in Scheme 8.

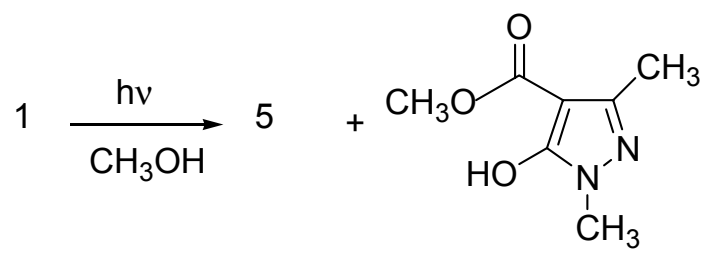

18

\section{Scheme 8}

\section{Experimental Section}

General Procedures. All melting points were determined using a MEL-TEMP apparatus and are uncorrected. ${ }^{1} \mathrm{H}$ NMR spectra $(400 \mathrm{MHz})$ and ${ }^{13} \mathrm{C}$ NMR spectra $(100 \mathrm{MHz})$ were recorded on a Bruker FT-NMR system. ${ }^{1} \mathrm{H}$ and ${ }^{13} \mathrm{C}$ chemical shifts were measured relative to internal TMS 
(0 ppm) and $\mathrm{CDCl}_{3}(77.0 \mathrm{ppm})$ respectively. UV absorption spectra were recorded in $1.0 \mathrm{~cm}$ matched quartz cells using a Hitachi U-2000 spectrometer. HPLC analyses were carried out on a Waters Model 510 system equipped with a C-18 $90 \AA 5$ m 3.9 x 300 mm column. Analysis of the photoreactions of $\mathbf{1}$ or $\mathbf{2}$ were carried out using a mobile phase of $75 \%$ methanol- $25 \%$ water ( $\left.0.50 \mathrm{ml} \mathrm{min}^{-1}\right)$ or $65 \%$ methanol-35\% water $\left(0.5 \mathrm{ml} \mathrm{min}^{-1}\right)$ respectively. Preparative layer chromatography was carried out on $20-\mathrm{cm}$ x 20-cm glass plates coated with $2 \mathrm{~mm}$ Kieselgel 60 $\mathrm{F}_{254}$ (Merck).

1-(5-Hydroxy-1,3-dimethyl-1H-pyrazol-4-yl)butane-1,3-dione (4a) and 1-(5-hydroxy-3methyl-1-phenyl-1H-pyrazol-4-yl)butane-1,3-dione (4b). A solution of dehydroacetic acid $N$ methylhydrazone $(\mathbf{3 a})^{29}(1.00 \mathrm{~g}, 5.10 \mathrm{mmol})$ or dehydroacetic acid $N$-phenylhydrazone $(\mathbf{3 b})^{30}$ $(2.64 \mathrm{~g}, 10.2 \mathrm{mmol})$ in glacial acetic acid $(20 \mathrm{ml})$ was refluxed for 1 hour. Evaporation of the solvent gave crude $4 \mathbf{a}(1.06 \mathrm{~g})$ or $\mathbf{4 b}(2.81 \mathrm{~g})$ which was recrystallized from ethyl acetate or acetonitrile.

4a was obtained as yellow crystals: mp $136-137^{\circ} \mathrm{C}$; yield $0.75 \mathrm{~g}(3.83 \mathrm{mmol}, 75 \%){ }^{1} \mathrm{H} \mathrm{NMR}$ $\left(\mathrm{CDCl}_{3}\right)$ enol (major) $\delta 15.0(\mathrm{~s}, 1 \mathrm{H}), 11.3(\mathrm{br}, \mathrm{OH}), 5.61(\mathrm{~s}, 1 \mathrm{H}), 3.56(\mathrm{~s}, 3 \mathrm{H}), 2.34(\mathrm{~s}, 3 \mathrm{H}), 2.11$ $(\mathrm{s}, 3 \mathrm{H})$; keto (minor) $\delta 11.3(\mathrm{br}, \mathrm{OH}), 3.80(\mathrm{~s}, 2 \mathrm{H}), 3.56(\mathrm{~s}, 3 \mathrm{H}), 2.33(\mathrm{~s}, 3 \mathrm{H}) 2.29(\mathrm{~s}, 3 \mathrm{H}) ;{ }^{13} \mathrm{C}$ NMR enol (major) $\delta 188.6,181.5,158.9,146.4,99.9,97.1,32.9,22.8,15.8$; keto (minor) $\delta 188.6$, $181.5,159.6,147.1,103.6,55.6,32.9,31.1,15.5$; $\mathrm{MS}(\mathrm{ESI}):(\mathrm{M}+\mathrm{Na})^{+}=218.8$.

4b was obtained as a yellow solid: mp $95-97^{\circ} \mathrm{C}$; yield $1.90 \mathrm{~g}(7.34 \mathrm{mmol}, 72 \%)$; ${ }^{1} \mathrm{H}$ NMR $\left(\mathrm{CDCl}_{3}\right)$ enol (major) $\delta 14.9(\mathrm{~s}, 1 \mathrm{H}), 12.2(\mathrm{br}, \mathrm{OH}), 7.81(\mathrm{~d}, \mathrm{~J}=8.3 \mathrm{~Hz}, 2 \mathrm{H}) 7.47(\mathrm{t}, \mathrm{J}=7.6 \mathrm{~Hz}$, $2 \mathrm{H}), 7.33(\mathrm{t}, \mathrm{J}=6.8 \mathrm{~Hz}, 1 \mathrm{H}), 5.71(\mathrm{~s}, 1 \mathrm{H}), 2.47(\mathrm{~s}, 3 \mathrm{H}), 2.11(\mathrm{~s}, 3 \mathrm{H})$; keto (minor) $\delta 12.2(\mathrm{br}$, $\mathrm{OH}), 7.81(\mathrm{~d}, \mathrm{~J}=8.3 \mathrm{~Hz}, 2 \mathrm{H}), 7.47(\mathrm{t}, \mathrm{J}=7.6 \mathrm{~Hz}, 2 \mathrm{H}), 7.33(\mathrm{t}, \mathrm{J}=6.8 \mathrm{~Hz}, 1 \mathrm{H}) 3.89(\mathrm{~s}, 2 \mathrm{H}), 2.46$ $(\mathrm{s}, 3 \mathrm{H}), 2.35(\mathrm{~s}, 3 \mathrm{H}) ;{ }^{13} \mathrm{C} \mathrm{NMR}\left(\mathrm{CDCl}_{3}\right)$ enol (major) $\delta 188.6,181.2,158.7,147.1,137.2,129.2$, $126.9,120.9,100.5,96.8,22.5,15.6$; keto (minor) $\delta 188.6,181.2,158.7,147.1137 .2,129.2$, $126.9,120.9,100.5,54.9,30.9,15.3$; MS (ESI) $(\mathrm{M}+\mathrm{Na})^{+}=281.1$.

\section{1,3,6-Trimethylpyrano[2,3-c]pyrazole-4(1H)-one (1) and 3,6-Dimethyl-1-phenyl-}

pyrano[2,3-c]pyrazole-4(1H)-one (2). Concentrated sulfuric acid $(0.30 \mathrm{ml})$ was added dropwise to a solution of $4 \mathbf{a}(0.60 \mathrm{~g}, 3.06 \mathrm{mmol})$ or $4 \mathbf{b}(1.33 \mathrm{~g}, 5.15 \mathrm{mmol})$ in glacial acetic acid (15 ml) and the mixture was heated at reflux for 1 hour and cooled to room temperature.

In the case of the N-methyl compound, the resulting solution was neutralized with saturated aqueous sodium carbonate and extracted with dichloromethane $(40 \mathrm{~mL})$. The extract was dried (sodium sulfate) and concentrated to give crude $1(0.49 \mathrm{~g})$, which was recrystallized from ethyl acetate.

In the case of the N-phenyl compound, the resulting solution was poured into cold water $(50 \mathrm{~mL})$. The precipitate was collected by filtration and washed with aqueous sodium carbonate (5\%), water, and dried to furnish crude 2 (1.22 g) which was recrystallized from acetonitrile.

1 was obtained as white crystalline solid; mp $154-155^{\circ} \mathrm{C}$, yield $0.40 \mathrm{~g}(2.27 \mathrm{mmol}, 74 \%) ;{ }^{1} \mathrm{H}$ $\operatorname{NMR}\left(\mathrm{CDCl}_{3}\right) \delta 5.94(\mathrm{~s}, 1 \mathrm{H}), 3.80(\mathrm{~s}, 3 \mathrm{H}), 2.51(\mathrm{~s}, 3 \mathrm{H}), 2.35(\mathrm{~s}, 3 \mathrm{H}) ;{ }^{13} \mathrm{C} \mathrm{NMR}\left(\mathrm{CDCl}_{3}\right) \delta 176.2$, 161.6, 154.8, 145.7, 112.4, 105.5, 34.1, 19.8, 14.2; UV(CH $\left.3{ }_{3} \mathrm{CN}\right) 250 \mathrm{~nm}\left(\varepsilon=9,608 \mathrm{~L} \mathrm{~mol}^{-1} \mathrm{~cm}^{-1}\right)$ 
and $206.0\left(\varepsilon=14,764 \mathrm{~L} \mathrm{~mol}^{-1} \mathrm{~cm}^{-1}\right)$; MS (ESI): $(\mathrm{M}+\mathrm{H})^{+}=179.1$; Anal. Calcd. for $\mathrm{C}_{9} \mathrm{H}_{10} \mathrm{~N}_{2} \mathrm{O}_{2}$ : C 60.66; H, 5.66; N, 15.72. Found: C, 60.52; H 5.94; N, 15.43 .

2 was obtained as colorless crystals: mp $148-149^{\circ} \mathrm{C}\left(\right.$ lit. $\left.^{22} 150^{\circ} \mathrm{C}\right)$; yield $0.99 \mathrm{~g}(4.12 \mathrm{mmol}$, $80 \%) ;{ }^{1} \mathrm{H} \mathrm{NMR}\left(\mathrm{CDCl}_{3}\right) \delta 7.77(\mathrm{~d}, \mathrm{~J}=8.6 \mathrm{~Hz}, 2 \mathrm{H}), 7.49(\mathrm{t}, \mathrm{J}=7.6 \mathrm{~Hz}, 2 \mathrm{H}), 7.36(\mathrm{t}, \mathrm{J}=7.6 \mathrm{~Hz}$, $1 \mathrm{H}), 6.04(\mathrm{~s}, 1 \mathrm{H}) 2.62(\mathrm{~s}, 3 \mathrm{H}), 2.40(\mathrm{~s}, 3 \mathrm{H}) ;{ }^{13} \mathrm{C} \mathrm{NMR}\left(\mathrm{CDCl}_{3}\right) 8175.7,161.6,153.5,146.8$, 137.1, 129.4, 127.3, 120.9, 112.6, 106.8, 19.6, 14.0; UV(CH $\left.{ }_{3} \mathrm{CN}\right) 242.5\left(\varepsilon=24,646 \mathrm{~L} \mathrm{~mol}^{-1} \mathrm{~cm}^{-}\right.$ $\left.{ }^{1}\right)\left[\mathrm{Lit}^{22}(\mathrm{EtOH}) 244 \mathrm{~nm}\left(\varepsilon=23.0 \times 10^{3}\right)\right]$; MS (SEI): $(\mathrm{M}+\mathrm{Na})^{+}=263.2$.

Ethyl 5-hydroxy-1,3-dimethyl-1 H-pyrazole-4-carboxylate (9). Diethyl 2-acetylmalonate (11). Sodium hydride $(60 \%$ dispersion, $30 \mathrm{mmol}, 1.20 \mathrm{~g})$ and tetrahydrofuran $(25 \mathrm{~mL})$ were added to a round bottom flask which had been flame-dried and flushed with argon. The mixture was cooled to $0^{\circ} \mathrm{C}$. Diethyl malonate was added to the stirred mixture and after 15 minutes at $0^{\circ} \mathrm{C}$, acetyl chloride $(562 \mathrm{mmol}, 40 \mathrm{~mL})$ was added dropwise. The resulting solution was stirred for 1 hour at $0^{\circ} \mathrm{C}$ and 12 hours at room temperature. The resulting solution was concentrated under vacuum, cooled to $0^{\circ} \mathrm{C}$, and quenched with water $(25 \mathrm{~mL})$, and the aqueous mixture extracted with dichloromethane $(2 \times 20 \mathrm{~mL})$. The combined extract was dried $\left(\mathrm{Na}_{2} \mathrm{SO}_{4}\right)$, concentrated, and the residual oil purified by bulb-to-bulb distillation $\left(90^{\circ} \mathrm{C}, 0.25 \mathrm{~mm}\right)$ to give 11 as a colorless liquid; yield $3.03 \mathrm{~g}(150.0 \mathrm{mmole}, 60 \%) ;{ }^{1} \mathrm{H}$ NMR $\left(\mathrm{CDCl}_{3}\right) \delta 13.7(\mathrm{~s}, \mathrm{OH}), 4.41$ (s, 1H) 4.20-4.29 (m, 4H), 2.17-2.32 (m, 3H), $1.25-1.32(\mathrm{~m}, 6 \mathrm{H}) ;{ }^{13} \mathrm{C} \mathrm{NMR}\left(\mathrm{CDCl}_{3}\right)$ major (enol) $\delta 181.5,171.9,166.8,101.5,61.6,62.2,21.5,14.8,14.7$; minor (keto) $\delta 197.5,165.2,66.6$, 63.3, 29.8, 14.6; MS (ESI : $(\mathrm{M}+\mathrm{Na})^{+}=225.0$.

Ethyl 5-hydroxy-1,3-dimethyl-1H-pyrazole-4-carboxylate (9). Methylhydrazine $(0.044 \mathrm{~g}$, $1.0 \mathrm{mmol})$ was added to a solution of $\mathbf{1 1}(0.21 \mathrm{~g}, 1.0 \mathrm{mmol})$ and concentrated hydrochloric acid $(0.20 \mathrm{ml})$ in ethanol $(10 \mathrm{~mL})$. After the mixture was heated at reflux for 2 hours and cooled to room temperature, the resulting solution was treated with water $(10 \mathrm{~mL})$ and extracted with dichloromethane $(20 \mathrm{~mL})$. The extract was dried $\left(\mathrm{Na}_{2} \mathrm{SO}_{4}\right)$ and evaporated to give $9(0.17 \mathrm{~g})$ which was recrystallized from acetonitrile to give 9 as colorless crystals : mp $124-125^{\circ} \mathrm{C}\left(\mathrm{Lit}^{27}\right.$ $\left.142-143^{\circ} \mathrm{C}\right)$; yield $0.114 \mathrm{~g}(0.62 \mathrm{mmol}, 62 \%) ;{ }^{1} \mathrm{H}$ NMR $\left(\mathrm{CDCl}_{3}\right) \delta 9.24(\mathrm{br}, \mathrm{OH}), 4.28(\mathrm{q}, \mathrm{J}=7.1$ $\mathrm{Hz}, 2 \mathrm{H}), 3.58(\mathrm{~s}, 3 \mathrm{H}) 2.29(\mathrm{~s}, 3 \mathrm{H}), 1.24(\mathrm{t}, \mathrm{J}=7.1 \mathrm{~Hz}, 3 \mathrm{H}),{ }^{13} \mathrm{C} \mathrm{NMR}\left(\mathrm{CDCl}_{3}\right)$ 8167.2, 157.7, 147.6, 92.7, 60.7, 33.3, 14.8, 14.6; MS (ESI) : $(\mathrm{M}+\mathrm{H})^{+}=185.3$.

Ethyl 5-hydroxy-3-methyl-1-phenyl-1H-pyrazole-4-carboxylate (13) Phenylhydrazine $(0$. $11 \mathrm{~g}, 1.08 \mathrm{mmol})$ was added to a solution of $11(0.21 \mathrm{~g}, 1.0 \mathrm{mmol})$ and concentrated hydrochloric acid $(0.20 \mathrm{~mL})$ in ethanol $(10 \mathrm{~mL})$. After the mixture was heated at reflux for 2 hours and cooled to room temperature, the resulting solution was treated with water $(10 \mathrm{~mL})$ and extracted with dichloromethane $(20 \mathrm{~mL})$. The extract was dried $\left(\mathrm{Na}_{2} \mathrm{SO}_{4}\right)$ and evaporated to give $13(0.221 \mathrm{~g})$ which was recrystallized from aqueous methanol to give $\mathbf{1 3}$ as a white crystalline product : $\mathrm{mp} 114-115^{\circ} \mathrm{C}\left(\mathrm{Lit}^{28} 114-115^{\circ} \mathrm{C}\right)$; yield $0.150 \mathrm{~g}(0.610 \mathrm{mmol}, 61 \%) ;{ }^{1} \mathrm{H} \mathrm{NMR}\left(\mathrm{CDCl}_{3}\right)$ $\delta 10.1(\mathrm{br}, \mathrm{OH}), 7.75(\mathrm{~d}, \mathrm{~J}=7.6 \mathrm{~Hz}, 2 \mathrm{H}), 7.41(\mathrm{t}, \mathrm{J}=8.3 \mathrm{~Hz}, 2 \mathrm{H}), 7.25(\mathrm{t}, \mathrm{J}=7.6 \mathrm{~Hz}, 1 \mathrm{H}), 4.30$ $(\mathrm{q}, \mathrm{J}=7.3 \mathrm{~Hz}, 2 \mathrm{H}), 2.36(\mathrm{~s}, 3 \mathrm{H}), 1.33(\mathrm{t}, \mathrm{J}=7.1 \mathrm{~Hz}, 3 \mathrm{H}),{ }^{13} \mathrm{C} \mathrm{NMR}\left(\mathrm{CDCl}_{3}\right) \delta 167.7,157.8$, $148.9,137.9,129.5,127.1,121.5,94.1,61.0,14.8 ; \mathrm{MS}(\mathrm{ESI}):(\mathrm{M}+\mathrm{H})^{+}=247.4$. 


\section{Irradiation procedures}

Analytical scale. A solution of the pyranopyrazole 1 or $2\left(3.0 \mathrm{~mL}, 2.0 \times 10^{-2} \mathrm{M}\right)$ in either acetonitrile or ethanol was placed in a quartz tube $(7.0 \mathrm{~mm}$ i.d. x $10.0 \mathrm{~cm}$ long), sealed with a rubber septum, purged with argon for 10 minutes and irradiated in a Rayonet reactor equipped with 14 low pressure mercury lamps. Aliquots (5.0 microliters) were removed periodically for analysis by HPLC.

Preparative scale. A solution of the pyranopyrazole 1 or $2\left(20.0 \mathrm{~mL}, 2.0 \times 10^{-2} \mathrm{M}\right)$ in either acetonitrile or ethanol was placed in a quartz tube $(1.0 \mathrm{~cm}$ i.d. x $22.0 \mathrm{~cm}$ long), sealed with a rubber septum, purged with argon for 20 minutes and irradiated in a Rayonet reactor equipped with 14 low pressure mercury lamps. Aliquots (5.0 microliters) were removed periodically for analysis by HPLC.

Irradiation of 1 in acetonitrile. Preparative-layer chromatography of the residue after evaporation of the solvent showed a band at $\mathrm{Rf}=0.40$ due to unconsumed reactant and a second band at $\mathrm{Rf}=0.25$ which provided dimer 5 as a white crystalline solid, mp 229-230 ${ }^{\circ} \mathrm{C}$. ${ }^{1} \mathrm{H} \mathrm{NMR}$ $\left(\mathrm{CDCl}_{3}\right) \delta 1.78(\mathrm{~s}, 6 \mathrm{H}), 2.28(\mathrm{~s}, 6 \mathrm{H}), 3.41(\mathrm{~s}, 6 \mathrm{H}), 3.22(\mathrm{~s}, 2 \mathrm{H}) ;{ }^{13} \mathrm{C} \mathrm{NMR}\left(\mathrm{CDCl}_{3}\right) \delta 14.2,28.3$, 33.6, 60.6, 86.3, 101.0, 147.4, 157.5, 180.0; IR (powder) 3983, 2944, 1658, 1563, 1491, 1106, 755, $682 \mathrm{~cm}^{-1}$; MS, M/Z (\%) 356 (58), 218 (100), 139 (84), 80 (55). Anal. Calcd. for $\mathrm{C}_{18} \mathrm{H}_{20}$ $\mathrm{N}_{4} \mathrm{O}_{4}: \mathrm{C}, 60.67 ; \mathrm{H}, 5.66 ; \mathrm{N}, 15.72$. Found: C, 60.60; H, 5.56; N, 15.52.

Irradiation of 1 in ethanol. Preparative layer chromatography of the residue after evaporation of the solvent showed a band at $\mathrm{Rf}=0.40$ due to unconsumed reactant, a band at $\mathrm{Rf}=0.25$ due to dimer $\mathbf{5}$, and a band at $\mathrm{Rf}=0.30$ which provided ethyl ester $\mathbf{9}$ as a white crystalline solid, $\mathrm{mp}$ 124-125 ${ }^{\circ}$. ${ }^{1} \mathrm{H} \mathrm{NMR}\left(\mathrm{CDCl}_{3}\right) \delta 9.24$ (br. s, $\mathrm{D}_{2} \mathrm{O}$ exchangeable, $\left.1 \mathrm{H}\right), 4.28(\mathrm{q}, \mathrm{J}=7.0 \mathrm{~Hz}, 2 \mathrm{H})$, $3.58(\mathrm{~s}, 3 \mathrm{H}), 2.29$ (s, 3H), $1.24\left(\mathrm{t}, \mathrm{J}=7.1 \mathrm{~Hz}, 3 \mathrm{H} ;{ }^{13} \mathrm{C} \mathrm{NMR}\left(\mathrm{CDCl}_{3}\right)\right.$ 167.2, 157.7, 147.6, 92.7, 60.7, 33.3, 14.8, 14.6; MS(ESI); $(\mathrm{M}+\mathrm{H})^{+}=185.3$.

Irradiation of 2 in acetonitrile. Preparative layer chromatography of the residue after evaporation of the solvent showed a band at $\mathrm{Rf}=0.45$ due to unconsumed reactant 2 and a second band at $\mathrm{Rf}=0.5$ which provided dimer $\mathbf{1 0}$ as a white crystalline solid, mp $180-181^{\circ} \mathrm{C}$; ${ }^{1} \mathrm{H}$ NMR $\left(\mathrm{CDCl}_{3}\right) \delta 1.82(\mathrm{~s}, 3 \mathrm{H}), 2.28(\mathrm{~s}, 3 \mathrm{H}), 3.23$ ( s, 1H ), 7.47 (d, 2H, J=7.6 Hz ), 7.39 ( t, $2 \mathrm{H}, \mathrm{J}=7.3 \mathrm{~Hz}), 7.26(\mathrm{t}, 1 \mathrm{H}, \mathrm{J}=7.6 \mathrm{~Hz}) ;{ }^{13} \mathrm{C} \mathrm{NMR}\left(\mathrm{CDCl}_{3}\right) \delta 180.0,156.7,148.6,137.0,127.5$, 121.3, 101.7, 87.8, 60.3, 28.3, 14.1; IR (powder) 3071, 2996, 2971, 1672, 1524, $1487 \mathrm{~cm}^{-1}$; MS, $\mathrm{M}+\mathrm{H} / \mathrm{Z}$ (\%) 481 (67), 281, (15), 241 (28), 219 (29), 201 (30), 157(45), 139 (33), 124 (21), 82 (100). Anal. Calcd. for $\mathrm{C}_{28} \mathrm{H}_{24} \mathrm{~N}_{4} \mathrm{O}_{4}: \mathrm{C}, 69.99 ; \mathrm{H}, 5.03 ; \mathrm{N}$ 11.66. Found : C,69.75; H, 4.75; N, 11.41 . 
Irradiation of 2 in ethanol. Preparative-layer chromatography of the residue after evaporation of the solvent showed a band at $\mathrm{Rf}=0.45$ due to unconsumed reactant 2 , a band at $\mathrm{Rf}=0.5$ due to dimer 10, and a band at 0.80 that provided ethyl ester $\mathbf{1 3}$ as a white crystalline compound, $\mathrm{mp}$ 114- $115^{\circ} \mathrm{C} ;{ }^{1} \mathrm{H}$ NMR $\left(\mathrm{CDCl}_{3}\right) \delta 10.1$ (br. s, $1 \mathrm{H}, \mathrm{D}_{2} \mathrm{O}$ exchangable), $7.75(\mathrm{~d}, \mathrm{~J}=7.6 \mathrm{~Hz}, 2 \mathrm{H}), 7.41$ $(\mathrm{t}, \mathrm{J}=8.3 \mathrm{~Hz}, 2 \mathrm{H}), 7.25(\mathrm{t}, \mathrm{J}=6.0 \mathrm{~Hz}, 1 \mathrm{H}), 4.30(\mathrm{q}, \mathrm{J}=7.3 \mathrm{~Hz}, 2 \mathrm{H}), 2,36(\mathrm{~s}, 3 \mathrm{H}), 1.33(\mathrm{t}, \mathrm{J}=7.3$ $\mathrm{Hz}, 3 \mathrm{H}):{ }^{13} \mathrm{C} \mathrm{NMR}\left(\mathrm{CDCl}_{3}\right) \delta 167.7,157.8,148.9,137.9,129.2,127.1,121.5,94.1,61.0,14.79$, 14.78; IR (powder) 3063, 3039, 2985, 2930, 1693, 1530, $1499 \mathrm{~cm}^{-1}$, MS: M+H/Z (\%) 247 (100), 219 (46), 207 (12), 201 (70), 185 (14), 158 (13), 139 (16).

Determination of X-ray crystal structures. Single crystal X-ray diffraction data were collected on a Bruker SMART/CCD diffractometer with graphite monochromated Mo-K $\alpha$ radiation and equipped with an LT-II low temperature device. Diffracted data were corrected for absorption using the SADABS program. SHELXS-86 and SHELXL-93 software were used to solve and refine structures. Refinement was based on $\mathrm{F}^{2}$. All non-hydrogen atoms were refined anisotropically. Hydrogen atoms were fixed in calculated positions and refined isotropically with thermal parameters based upon the corresponding attached carbon atoms $[\mathrm{U}(\mathrm{H})=1.2 \mathrm{Ueq}(\mathrm{C})]$. Crystallographic data for 5c. $\mathrm{C}_{18} \mathrm{H}_{20} \mathrm{~N}_{4} \mathrm{O}_{4}$, colorless plate, $153(2) \mathrm{K}, M=356.38$, monoclinic, space group $C 2 / c, a=13.915(2) \AA, b=9.0941(15) \AA, c=13.137(2) \AA, \beta=96.129(3)^{\circ}, V=$ $1653.0(5) \AA^{3}, Z=4, D_{c}=1.43 \mathrm{~g} / \mathrm{cm}, \mathrm{Mo}_{\alpha}, \mu=0.104 \mathrm{~mm}^{-1}, 1370$ data with $I>2 \sigma(I), R=$ $0.046, R_{w}=0.096$. Data were collected on a Bruker SMART CCD and structural determination was carried out using Bruker SHELXTL software. CCDC reference number 693018.

\section{Acknowledgements}

Vuthichai Ervithayasuporn acknowledges financial support from The Development and Promotion of Science and Technology Talent Project, Bangkok, Thailand.

\section{References}

1. Paterno, E. Gazz. Chim. Ital. 1914, 44, 151.

2. Giua, M.; Civera, M. Gazz. Chim. Ital. 1951, 81, 875.

3. Yates, P.; Jorgenson, M. J. J. Am. Chem. Soc. 1958, 80, 6150.

4. Yates, P.; Jorgenson, M. J. J. Am. Chem. Soc. 1963, 85, 2956.

5. Ishibi, N.; Odani, M.; Sunami, M. J. Chem. Soc., Chem. Commun. 1971, 1034.

6. Ishibi, N.; Odani, M.; Sunami, M. J. Am. Chem. Soc. 1973, 95, 463.

7. Pavlik, J. W.; Kwong, J. J. Am. Chem. Soc. 1973, 95, 7914.

8. Barltrop, J. A.; Day, A. C.; Samuel, C. J. J. Am. Soc. Chem. Commun. 1977, 598.

9. Barltrop, J. A.; Day, A. C.; Samuel, C. J. J. Am. Chem. Soc. 1979, 101, 7521. 
10. Keil, E. B.; Pavlik, J. W. J. Heterocyclic Chem. 1976, 13, 1149.

11. Pavlik, J. W.; Pauliukonis, L. T. Tetrahedron Lett. 1976, 1439.

12. Pavlik, J. W.; Snead, T. E.; Tata, J. R. J. Heterocylic Chem. 1981, $18,1481$.

13. Pavlik, J. W.; Kirincich, S. J.; Pires, R. M. J. Heterocyclic Chem. 1991, 28, 537.

14. West, F. G.; Fisher, P. V.; Willoughby, C. A. J. Org. Chem. 1990, 55, 5936.

15. Tiefenthaler, H.; Dorschelen, W.; Goth, H.; Schmid, H. Helv. Chim. Acta 1967, 50, 2244.

16. Beak, P.; Miesel, J. L.; Messer, W. R. Tetrahedron Lett. 1967, 5315.

17. Beak, P.; Messer, W. R. Tetrahedron 1969, 25, 3287.

18. Barltrop, J. A.; Day, A. C.; Mac, A. G.; Shahrisa, A., Wakamatsu, S. J. Chem. Soc. Chem. Commun. 1981, 604.

19. Pavlik, J. W.; Kurzweil, E. M. J. Org. Chem. 1991, 56, 6313.

20. Pavlik, J. W.; Kebede, N. J. Org. Chem. 1997, 62, 8325.

21. Pavlik, J. W.; Kebede, N.; Bird, N. P.; Day, A. C.; Barltrop, J. A. J. Org. Chem. 1995, 60, 8138.

22. Gelin, S.; Changtegrel, B.; Nadi, A. I. J. Org. Chem. 1983, 48, 4078.

23. Although compounds $\mathbf{4 a}, \mathbf{4 b}$ and $\mathbf{2}$ (see also reference 24) have been described in the literature, 1 has not been previously reported.

24. Kahn,M.A.; Pagotto, M. C.; Ellis, G. P. Heterocycles 1977, 6, 983.

25. The weaker $n, \pi^{*}$ absorption transitions were not observed and are presumably buried under the more intense $\pi, \pi^{*}$ absorptions.

26. Schmidt, K.; Kopf, J.; Margaretha, P. Helv. Chim. Acta 2006, 89, 1927.

27. Jursic, B.; Bregant, N. Synth. Commun. 1989, 19, 11.

28. Lopez, R.; Leon, G.; Oliva, A. J. Heterocyclic Chem. 1995, 32, 1377.

29. Cantos, A.; De March, P.; Moreno-Manas, M.; Pla, A.; Sanchez-Ferrando, F.; Virgili, A. Bull. Chem. Soc. Jpn. 1987, 60, 4425.

30. Perkin, Jr., W. H.; Bernhart, C. Ber. 1884, 17, 1522. 